\title{
AMYLIN INCREASES CYCLIC AMP FORMATION IN L6 MYOCYTES THROUGH CALCITONIN GENE-RELATED PEPTIDE RECEPTORS
}

\author{
GUOCHANG ZHU1', DAVID T. DUDLEY², AND ALAN R. SALTIEL 1,2, \\ 1Department of Physiology, The University of Michigan Medical School, \\ Ann Arbor, MI 48109
}

2Department of Signal Transduction, Parke-Davis Pharmaceutical Research Division, WarnerLambert Co., 2800 Plymouth Road, Ann Arbor, MI 48106

Received April 8, 1991

Summary: The cellular function of amylin is investigated in L6 myocytes, a rat skeletal muscle cell line. Both rat amylin and human amylin-amide acutely cause a dose-dependent increase in cyclic AMP formation in L6 myocytes. $100 \mathrm{nM}$ rat amylin stimulates intracellular cyclic AMP concentrations 12 -fold, whereas human amylin-amide at this concentration causes only a 2 -fold increase. Up to $10 \mathrm{mM}$ human amylin has no effect on cyclic AMP levels. Rat calcitonin generelated peptide (CGRP) is more potent than amylin, causing a 60 -fold increase over basal at $1 \mathrm{nM}$,

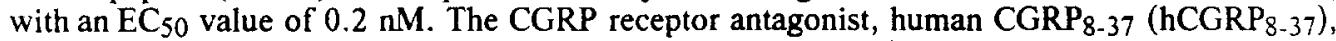
completely blocks the stimulatory effect of both rat amylin and human amylin-amide on cyclic AMP production. [125I]CGRP binds specifically to a membrane fraction prepared from L6 myocytes with a $\mathrm{Kd}=2.1 \mathrm{nM}$ and $\mathrm{Bmax}=144 \mathrm{fmol} / \mathrm{mg}$ protein. The antagonist peptide displaces [125I]CGRP with a $\mathrm{Ki}$ of $0.9 \mathrm{nM}$, while rat amylin also displaces [125I]CGRP with a Ki of $91 \mathrm{nM}$. Specific binding of [ $\left.{ }^{125} \mathrm{I}\right]$ CGRP to plasma membranes of rat liver and brain is also displaced by rat amylin with $\mathrm{Ki}$ values of $35 \mathrm{nM}$ and $37 \mathrm{nM}$, respectively. In contrast, specific binding of [125I] amylin to numerous cells and tissues, under similar conditions, can not be demonstrated. These results suggest that the cellular effects and physiological actions of amylin may be mediated through receptors for CGRP. 1991 Academic press, Inc.

Amylin is the major peptide component of the islet amyloid deposits that occur in over $90 \%$ of patients with Non-Insulin Dependent Diabetes Mellitus (NIDDM) and more than $75 \%$ of diabetic Pima Indians (1,2). Amylin has been isolated and characterized as a 37 amino acid peptide that is produced by pancreatic $B$-cells, co-packaged with insulin in secretory granules and co-secreted into the sinusoidal space. Human amylin exhibits almost 50 percent sequence identity to calcitonin gene-related peptide (CGRP), a neuropeptide hormone that is distributed widely in the nervous system and peripheral organs (3-5). Some evidence suggests that both amylin and CGRP may be involved in the pathogenesis of insulin resistance in NIDDM. Both peptides have been reported to lower basal and insulin-stimulated glycogen synthesis in skeletal muscle, as well as cause an acute

\footnotetext{
*To whom all correspondence should be addressed at present address: Department of Sigual Transduction, Parke-Davis Pharmareutical Research Division, Wamer-Lambert Co, 2800 Plymouth Road, Ann Arbor, MI 48106.
}

Abbreviations: CGRP, calcitonin gene-related peptide; DMEM, Dulbecco's modified Eagle's medium; NIDDM, non-insulin dependent diabetes mellitus; PMSF, phenylmethylsulfonyl fluoride. 
elevation in rates of hepatic glucose output in vivo (6-12). However, the cellular mechanism of amylin action remains unknown. To address this deficiency, we have investigated the cellular effects of amylin in L6 myocytes, a rat skeletal muscle cell line, as well as the binding of amylin to membranes from $L 6$ myocytes, rat liver and brain.

\section{Materials and Methods}

Materials: Sprague-Dawley rats $(250-350 \mathrm{~g})$ were obtained from Charles River Breeding Laboratories. Rat amylin, human amylin, human amylin-amide, rat CGRP and hCGRP8-37 were purchased from Peninsula Laboratories, Belmont, CA, and the purity of amylins were confirmed with standard analytical techniques. [125I]CGRP (human) and [125I]amylin (rat) were obtained from Amersham Co., Arlington Heights, IL. $\left[{ }^{3} \mathrm{H}\right]$ adenine was obtained from ICN Biochemicals, Costa Mesa, CA. Dulbecco's modified Eagle's medium (DMEM) was obtained from GIBCO Laboratories, Grand Island, NY. Pepstatin A, aprotinin and leupeptin were obtained from Boehringer Mannheim Biochemicals, Indianapolis, IN. Other chemicals were purchased from Sigma, St. Louis, MO.

Cell culture and assay of cyclic AMP: L6 myocytes were originally obtained from the American Type Culture Collection (Rockville, MD) and were maintained in DMEM supplemented with $10 \%$ fetal bovine serum. The activity of adenylyl cyclase was assayed by measuring the accumulation of $\left[{ }^{3} \mathrm{H}\right]$ cyclic AMP in cells pre-labelled with [ $\left.{ }^{3} \mathrm{H}\right]$ adenine. Cells grown to confluence in 12-well plates, were labeled for $3 \mathrm{~h}$ with $0.5 \mu \mathrm{Ci}$ [ ${ }^{3} \mathrm{H}$ ]adenine in $0.5 \mathrm{ml}$ of growth medium. After labeling, the cells were washed with minimal essential medium supplemented with $20 \mathrm{mM}$ HEPES, $1 \mathrm{mM}$ 3-isobutyl-1-methyl-xanthine and $0.1 \%$ bovine serum albumin. The cells were then treated with various conditions for $10 \mathrm{~min}$ at room temperature. The incubation was terminated by aspiration of medium and addition of $0.3 \mathrm{ml} 0.1 \mathrm{M} \mathrm{HCl}$ containing $1 \mathrm{mM}$ cyclic AMP. Total $\left[{ }^{3} \mathrm{H}\right]$ cyclic AMP was determined after sequential chromatography on Dowex and alumina columns (13).

Preparation of Plasma Membranes: Crude plasma membranes of L6 myocytes were prepared from cells grown in $150 \mathrm{~mm}$ culture plates. Cells were washed with ice-cold phosphate buffered saline and subsequently swollen in $5 \mathrm{mM}$ Tris buffer supplemented with EDTA, $10 \mu \mathrm{M}$ leupeptin, $10 \mu \mathrm{M}$ pepstatin $\mathrm{A}, 10 \mu \mathrm{M}$ bacitracin and $100 \mu \mathrm{M}$ phenylmethylsulfonyl fluoride (PMSF). Cells were removed from the plates by scraping with a rubber policeman and kept on ice for $15 \mathrm{~min}$, followed by disruption with a Brinkman Polytron PT-10 at setting 7 for 30 sec. Following sonication for $30 \mathrm{sec}$, the homogenate was centrifuged at $50,000 \times \mathrm{g}$ for $30 \mathrm{~min}$ and the resulting pellets were resuspended in $50 \mathrm{mM}$ Tris- $\mathrm{HCl}$ containing $100 \mathrm{mM} \mathrm{NaCl}, 10 \mathrm{mM} \mathrm{MgCl}$, $100 \mathrm{mM}$ PMSF, $10 \mathrm{mM}$ leupeptin, $10 \mathrm{mM}$ pepstatin $A$ and $10 \mathrm{mM}$ aprotinin.

In some experiments, plasma membranes were purified from fresh livers obtained from adult male Sprague-Dawley rats $(250-350 \mathrm{~g})$ as previously described (14). Briefly, livers were homogenized in $1 \mathrm{mM}$ sodium bicarbonate buffer, $\mathrm{pH} 8.0$, containing $10 \mathrm{mM}$ EGTA, $5 \mathrm{mM}$ EDTA, $100 \mu \mathrm{M}$ PMSF, $10 \mu \mathrm{M}$ leupeptin, $10 \mu \mathrm{M}$ pepstatin $\mathrm{A}$ and $10 \mu \mathrm{M}$ aprotinin. The liver homogenate was centrifuged for $10 \mathrm{~min}$ at $400 \times \mathrm{g}$, and the pellets were resuspended in $70 \%$ ( $w t / v o l$ ) sucrose to achieve a final sucrose concentration of $44 \%$ (wt/vol). Fifteen milliliters of $40 \%$ ( $w t / v o l)$ sucrose was layered over $22 \mathrm{ml}$ of the homogenate, and the preparation was centrifuged for $2 \mathrm{~h}$ at $122,000 \times \mathrm{g}$. The purified membranes were washed twice with phosphate buffered saline, $\mathrm{pH} 7.4$, at $4^{\circ} \mathrm{C}$. Plasma membranes from rat brain were prepared in a similar fashion, and the pellets resuspended in $50 \mathrm{mM}$ Tris- $\mathrm{HCl}$ buffer containing $100 \mathrm{mM} \mathrm{NaCl}$ and $10 \mathrm{mM} \mathrm{MgCl}$. Protein was assayed by the Bio-Rad dye-binding method using bovine serum albumin as standard. Membranes were stored in aliquots at $-70^{\circ} \mathrm{C}$ for up to 3 weeks.

Receptor binding assay: Radioligand binding to plasma membranes was assayed as described $(6,15,16)$ with slight modification. Membranes were incubated for $2 \mathrm{~h}$ at $4^{\circ} \mathrm{C}$ in a final volume of $0.5 \mathrm{ml}$ consisting of $50 \mathrm{mM}$ Tris- $\mathrm{HCl}$ buffer, $100 \mathrm{mM} \mathrm{NaCl}, 10 \mathrm{mM} \mathrm{MgCl}, 1 \%$ bovine serum albumin, $100 \mu \mathrm{M}$ bacitracin, $58 \mathrm{pM}$ [125I]CGRP or $200 \mathrm{pM}$ [125I] amylin and various concentrations of unlabeled ligands. Bound [125I]peptide was separated from free by rapid filtration through Whatman $\mathrm{GF} / \mathrm{C}$ glass filter sheets presoaked in $50 \mathrm{mM}$ Tris- $\mathrm{HCl}$ buffer, $\mathrm{pH} 7.7$, containing $0.5 \%$ of polyethylenimine (16) and $100 \mu \mathrm{m}$ bacitracin using a Brandel $48 \mathrm{R}$ cell 
harvester. The filters were washed three times with $4 \mathrm{ml}$ of Tris buffer and then counted for gamma radioactivity.

Data analysis: Saturation binding analysis was performed using the LIGAND program (17). $\mathrm{IC}_{50}$ and $\mathrm{EC}_{50}$ values were calculated by weighted nonlinear regression curve-fitting to the massaction equation.

\section{Results and Discussion}

Amylin and CGRP increase cyclic AMP formation in $\mathbf{6}$ myocytes. One of the mechanisms by which counter-regulatory hormones inhibit the insulin-dependent increase in glycogen synthesis in skeletal muscles is through elevation of cyclic AMP levels. To determine if amylin could modulate cyclic AMP, levels of cyclic AMP were assayed in L6 myocytes exposed to amylin or CGRP. CGRP acutely caused a large dose-dependent increase in intracellular cyclic AMP levels in L6 myocytes. Over a 60-fold stimulation was observed with 1nM CGRP, with an $\mathrm{EC}_{50}$ value of $0.2 \mathrm{nM}$ (Fig. 1). Both rat amylin and human amylin-amide similarly caused a dosedependent increase in cyclic AMP levels, albeit at much higher concentrations. In these experiments, concentrations of peptides greater than $10 \mu \mathrm{M}$ could not be used, due to solubility problems, so we were unable to explore whether the effect of amylin was saturable. Nevertheless, it is likely that both of the amylin peptides may be full agonists. Further, it is clear that rat amylin is approximately 10 fold more potent than human amylin-amide, whereas human amylin at concentrations up to $10 \mu \mathrm{M}$ was ineffective in raising cyclic AMP levels. These results parallel the predicted order of potency of amylin peptides studied in other systems $(7,10,11,18,19)$.

hCGRP 8-37 attenuates the stimulatory effect of amylin on cyclic AMP levels in L6 myocytes. To further explore the specificity of amylin, a specific CGRP receptor antagonist peptide, hCGRP ${ }_{8-37}$, was tested for its ability to block the amylin-stimulated increase in

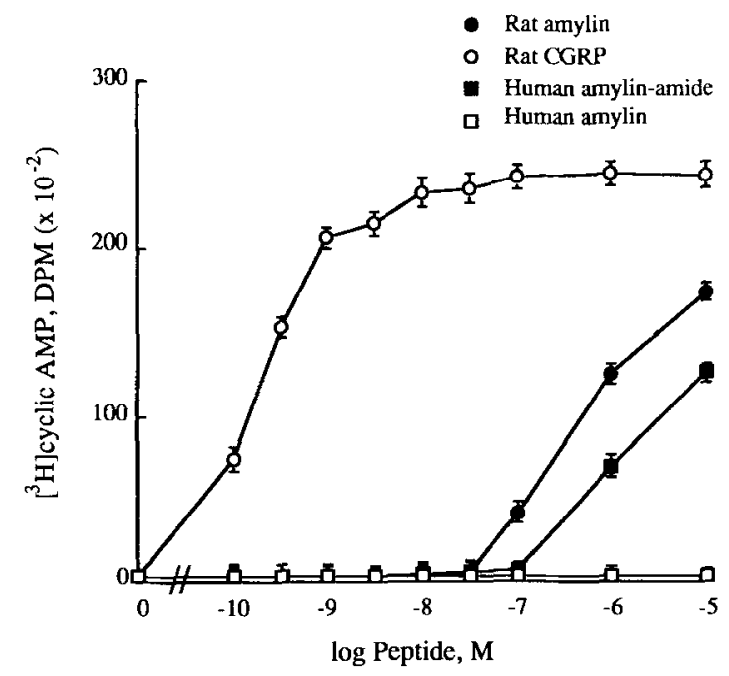

Fig. 1. CGRP and Amylin stimulate cAMP production in L6 myocytes. Cyclic AMP was assayed in $\mathrm{L} 6$ myocytes after stimulation with rat CGRP, rat amylin, human amylin-amide and human amylin. Confluent L6 myocytes were incubated for $10 \mathrm{~min}$ at room temperature in the presence of peptides. Data are presented as means \pm standard deviation of triplicate determinations, repeated in three separate experiments. 


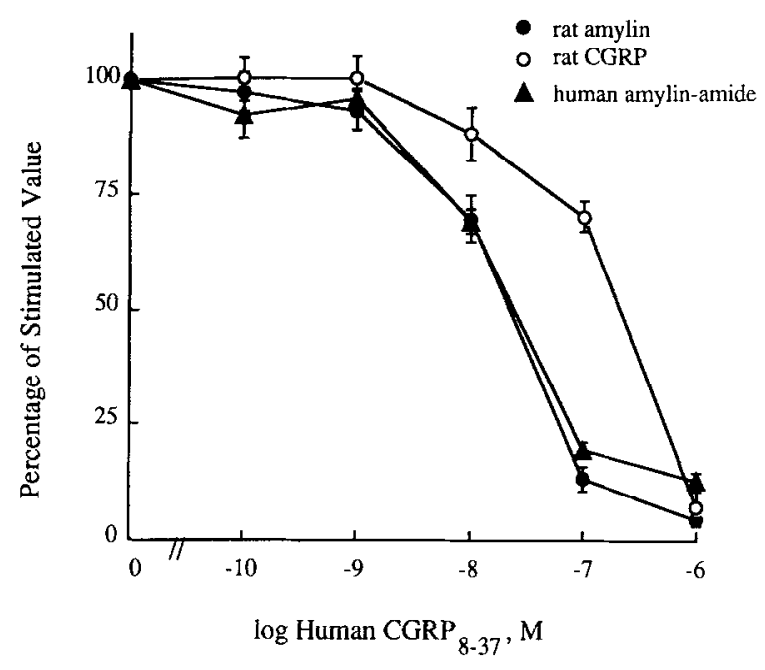

Fig. 2. The CGRP receptor antagonist, CGRP 8-37, attenuates the stimulatory effect of amylin on cAMP levels. After 5 min incubation with increasing concentration of human CGPP8-37, L6 myocytes were stimulated by either $10 \mathrm{nM}$ rat CGRP, $1 \mu \mathrm{M}$ rat amylin or 10 $\mu \mathrm{M}$ human amylin-amide for $10 \mathrm{~min}$ at room temperature. Results are presented as the means \pm standard deviation of triplicate determinations, repeated in three separate experiments.

cyclic AMP in L6 myocytes. hCGRP ${ }_{8-37}$ inhibited cyclic AMP formation in L6 myocytes stimulated by CGRP or by rat amylin and human amylin-amide in a dose-dependent manner (Fig. 2). $1 \mathrm{mM}$ hCGRP 8.37 caused a $94 \%$ inhibition of the stimulatory effect of $10 \mathrm{nM}$ CGRP and a 90 $98 \%$ inhibition of the stimulation caused by $1 \mu \mathrm{M}$ rat amylin or $10 \mu \mathrm{M}$ human amylin-amide.

Rat amylin displaces [125 I]CGRP specific binding. [125I]CGRP specifically bound to membranes prepared from L6 myocytes in a saturable manner, yielding a $\mathrm{Kd}$ of $2.1 \mathrm{nM}$ and Bmax of $144 \mathrm{fmol} / \mathrm{mg}$ protein. The specificity of [125I]CGRP binding to L6 myocytes was evaluated by competition binding assays using rat CGRP, hCGRP $8-37$ and rat amylin (Fig. 3A). Increasing concentrations of these peptides inhibited [125I]CGRP binding to plasma membranes of L6 myocytes in a dose-dependent fashion. Analysis of these data revealed that hCGRP 8.37 was almost as effective as rat CGRP in competing for [ $\left.{ }^{125} \mathrm{I}\right] \mathrm{CGRP}$ binding, yielding Ki values of 0.9 $\mathrm{nM}$ and $1.5 \mathrm{nM}$, respectively. Interestingly, rat amylin also displaced the binding of [ ${ }^{125}$ I]CGRP with a Ki of $91 \mathrm{nM}$.

Binding of [ ${ }^{125}$ I]CGRP to plasma membranes prepared from rat liver (Fig. 3B) and brain (Fig. 3C) was also investigated. Specific binding of [125I]CGRP was detected with Kd values of $1.2 \mathrm{nM}$ and $1.1 \mathrm{nM}$ and $B_{\max }$ values of $980 \mathrm{fmol} / \mathrm{mg}$ and $49 \mathrm{fmol} / \mathrm{mg}$ protein for rat liver and brain, respectively. Furthermore, in these tissues rat amylin also displaced [125I]CGRP binding, yielding Ki values of $35 \mathrm{nM}$ and $37 \mathrm{nM}$ for rat liver and brain, respectively (Fig. 3B and 3C).

Under similar conditions, we could demonstrate no specific binding of [125I] rat amylin, at concentrations up to $200 \mathrm{pM}$, to membranes from L6 cells, rat liver or brain (data not shown). Moreover, we were also unable to detect specific binding to membranes prepared from rat skeletal muscle or adipose tissue.

Taken together, these studies failed to provide evidence for a specific amylin receptor in various cells and tissues, including L6 myocytes, rat liver and brain. However, the observation 


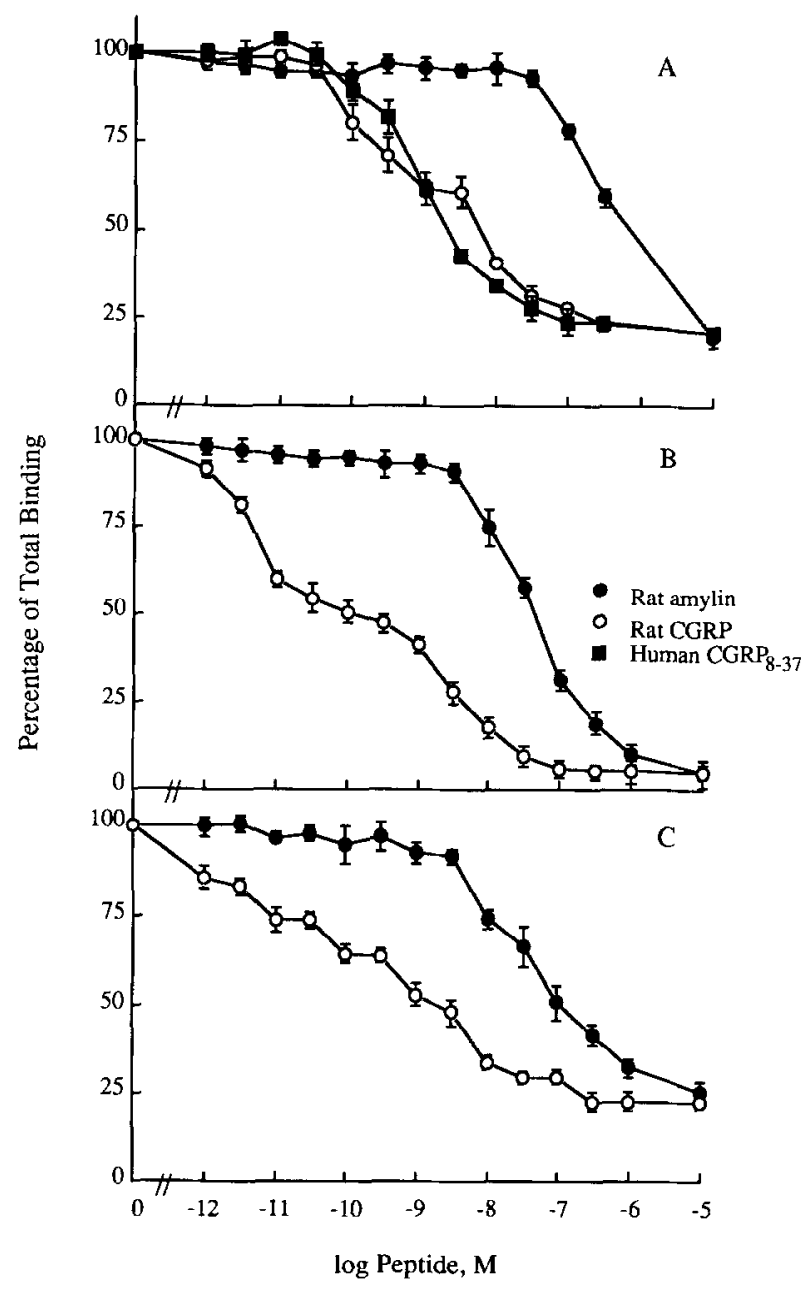

Fig. 3. The binding of [125I]CGRP to plasma membranes is displaced by Amylin peptides. [ ${ }^{125}$ I]CGRP binding was assayed in plasma membranes prepared from $\mathrm{L} 6$ myocytes (A), liver (B) or brain (C), in the presence of rat CGRP, rat amylin or human CGRP8-37. Plasma membranes were incubated for $2 \mathrm{~h}$ at $4^{\circ} \mathrm{C}$ with $49-58 \mathrm{pM}$ [125I]CGRP in the presence of varying concentrations of the peptides as indicated. Data are expressed as the percentage of maximal binding in absence of unlabeled peptides. Values are means \pm standard deviations of triplicate determinations, repeated in three separate experiments.

that nanomolar concentrations of amylin are biologically active in L6 myocytes is consistent with previous reports demonstrating that similar concentrations of amylin inhibit insulin-stimulated glycogen synthesis and glucose uptake in soleus muscle $(7,10,11,18,19)$. While the physiological role of amylin remains to be elucidated, it is apparent that its reported actions are likely to be mediated through CGRP receptors (20). This further suggests that amylin may share some of the actions of CGRP and have unappreciated effects on the vasculature and central nervous system.

Acknowledgment This work was supported by Grant DK33804 from the National Institute of Health. 


\section{References}

1. Clark, A., Saad, M.F., Nezzer, T., Uren, C., Knowler, W.C., Bennett, P.H. and Tumer, R.C. (1990) Diabetologia 33, 285-289

2. Clark, A., Wells, C.A., Buley, I.D., Cruickshank, J.K., Vanhegan, R., Matthews, D.R., Cooper, G.S., Holman, R.R. and Tumer, R.C. (1988) Diabetes Res. 9, 151-159

3. Johnson, K.H., O'Brien, T.D., Hayden, D.W., Jordan, K., Ghobrial, H.G., Mahoney, W.C. and Westermark, P. (1988) Am. J. Pathol. 130, 1-8

4. Leffert, J.D., Newgard, C.B., Okamoto, H., Milburn, J.L. and Luskey, K.L. (1989) Proc. Natl. Acad. Sci. USA 86, 3127-3130

5. Dennis, T., Foumier, A., Cadieux, A., Pomerleau, F., Jolicocur, F.B., Pierre, S.S. and Quirion, R. (1990) J. Pharmacol. Exp. Ther. 254, 123-128

6. Leighton, B. and Cooper, G.S. (1990) TIBS 15, 295-299

7. Leighton, B. and Foot, E. (1990) Biochem. J. 269, 19-23

8. Molina, J.M., Cooper, G.S., Leighton, B. and Olefsky, J.M. (1990) Diabetes 39, 260-265

9. Kreutter, D., Orena, S.J. and Andrews, K.M. (1989) Biochem. Biophys. Res. Commun. $164,461-467$

10. Leighton, B. and Cooper, G.S. (1988) Nature 335, 632-635

11. Roberts, A.N., Leighton, B., Todd, J.A., Cockbum, D., Schofield, P.N., Sutton, R., Holt, S., Boyd, Y., Day, A.J., Foot, E.A., Willis, A.C., Reid, K.M. and Cooper, G.S. (1989) Proc. Natl. Acad. Sci. USA 86, 9662-9666

12. Nishi, M., Sanke, T., Nagamatsu, S., Bell, G.I. and Steiner, D. (1990) J. Biol. Chem. $265,4173-4176$

13. Salomon, Y. (1979) Adv. Cyclic Nuc. Res. 10, 35-55

14. Fox, J.A., Soliz, N.M. and Saltiel, A.R. (1987) Proc. Natl. Acad. Sci. USA 84, $2663-$ 2667

15. Ilægerstrand, A., Dalsgaard, C.J., Jonzon, B., Larsson, O. and Nilsson, J. (1990) Proc. Natl. Acad. Sci. USA 87, 3299-3303

16. Bruns, R.F., Lawson-Wendling, K. and Pugsley, T.A. (1983) Anal. Biochem. 132, 74-81

17. Munson, P.J. and Rodbard, D. (1980) Anal. Biochem. 107, 220-239

18. Young, D.A., Deems, R.O., Deacon, R.W., Mcintosh, R.A. and Foley, J.A. (1990) Am J Physiol 259, E457-E461

19. Cooper, G.S., Leighton, B., Dimitriadis, G.D., Parry-Billings, M., Kowalchuk, J.M., Howland, K., Rothbard, J.B., Willis, A.C. and Reid, K.M. (1988) Proc. Natl. Acad. Sci. USA 85, 7763-7766

20. Morishita, T., Yamaguchi, A., Fujita, T. and Chiba, T. (1990) Diabetes 39, 875-877 